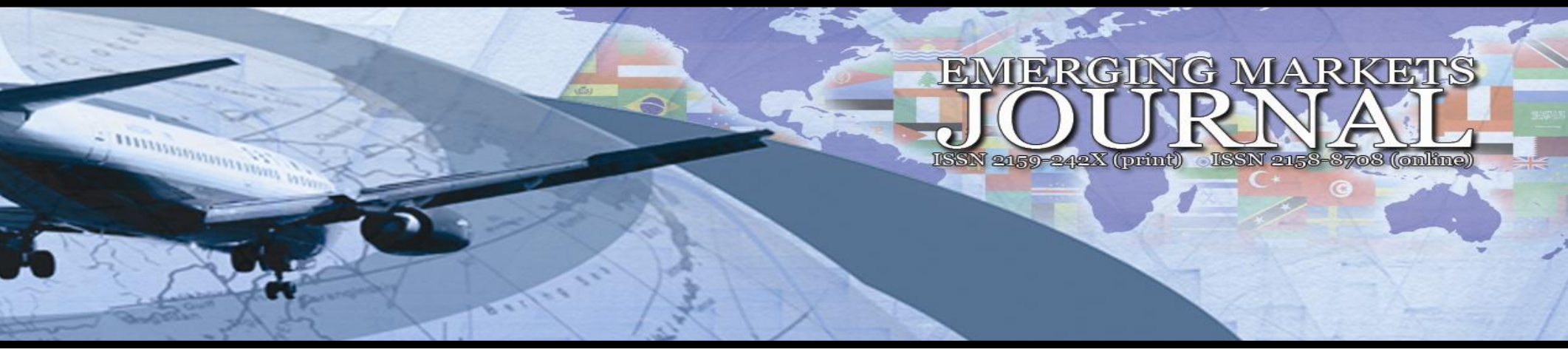

\title{
The Relationship between Gold Prices and Exchange Value of US Dollar in India
}

\section{Girish Karunakaran Nair}

Program Leader, International Hospitality Management, Stenden University, Doha - Qatar | email: gknair75@ gmail.com

\section{Nidhi Choudhary}

Assistant Professor, SBI School of Commerce \& Banking, Banasthali Unviersity, FMS-Wisdom, Rajasthan, India | email: nidhic10@gmail.com

\section{Harsh Purohit}

Dean, FMS-WISDOM, SBI School of Commerce \& Banking, Banasthali Unviersity, Rajasthan, India

| email: deanwisdom@ banasthali.in

\section{Volume 5 No 1 (2015) ｜ ISSN 2158-8708 (online) ｜ DOI 10.5195/emaj.2015.66 | http://emaj.pitt.edu |}

\section{Abstract}

The inverse relationship between the value of U.S. dollar and that of gold is one of the most talked about relationships in currency markets. The present study is an attempt to understand the impact of recession of 2008 on relationship between exchange rate of US dollar in INR and gold prices in India. The study uses Johansen Co- Integration test to check the long term association between exchange rate of US dollar in INR and gold prices in India and it further uses the Granger Causality Test to check the lead lag relationship between the variables. A separate pre, during and post recession analysis of the variables is done to understand the impact of recession on this relationship. The study highlights how this relationship has changed since the global turmoil.

Key Words: Gold Price; Value of Dollar; Johansen Co-Integration; Ganger Causality.

\section{$(\mathrm{Cc})$ EY}

New articles in this journal are licensed under a Creative Commons Attribution 3.0 United States License.

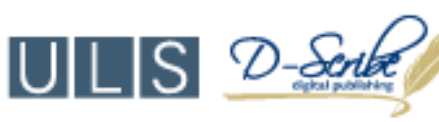

This journal is published by the University Library System of the University of Pittsburgh as part of its D-Scribe Digital Publishing Program, and is cosponsored by the University of Pittsburgh Press. 


\section{The Relationship between Gold Prices and Exchange Value of US Dollar in India}

\author{
Girish Karunakaran Nair \\ Nidhi Choudhary \\ Harsh Purohit
}

\section{Introduction}

Indians consider the yellow metal as an object of luxury believed to be worthy for only gods and rulers. The metal is a symbol of wealth, supremacy, beauty, and cream of the crop and holds immense religious magnitude in Indian culture. Indians are known for their love for gold. The jewelry demand for the metal is highest in India. The country consumed 864 Tones of metal in 2012 in the form of jewellery, bar and coins only (PWC, 2013) such high consumption statistics clearly show that the prices of gold is an important issue for the Indians.

The reverse relationship between the value of U.S. dollar and that of gold is one of the most discussed about relationships in currency markets. Dollar is an internationally accepted currency and most of the international transactions take place in dollar equivalent. The major reason behind the relationship of gold and USD INR exchange rate is that gold is used as a hedge against the adverse exchange value of dollar. As the dollar's exchange value decreases, it takes more dollars to buy gold, which increases the value of gold. The value of dollar can be at a potential risk of fluctuation through various factors like shifts in monetary policy, international trade, etc., but the value of yellow metal is largely determined by supply and demand, without interference from shifts in monetary and corporate policies. The relationship of gold and dollar is traced back to international history, discussed in next section.

\section{History of Gold and Dollar Relationship}

After the First World War, nations attempted to revive the gold standard for international exchange rates, but the system soon collapsed with the arrival of the Great Depression of the 1930s. Some economists were of the view that the strict obedience to the gold standard had prevented monetary authorities all over the world from increasing the money supply to match the growing demand for money which could have been enough to revive economic activity. Soon after the end of the Second World War, representatives of most of the world's leading nations met at Bretton Woods, New Hampshire, in 1944 to create a new international monetary system. United States had emerged as politically strong nation on the winner side after the war. It was the world leader in terms of manufacture capacity and accounted for over half of the world's capacity. The nation also held most of the world's gold at that time. Therefore, the leaders decided to tie world currencies to the dollar, which, in turn, they agreed should be convertible into gold at a fixed exchange rate of $\$ 35$ per ounce. This was known as the Bretton Woods System. The system required the central banks of countries other than that of United States to maintain a fixed exchange rate between their currencies and the dollar. The US Dollar could be internationally exchanged for gold. The central banks had to accomplish this task by intervening in foreign exchange markets. If the exchange value of a country's currency was too high relative to the dollar, its central bank would sell its currency in exchange for dollars, which will make the value of its currency to sink down. Conversely, if the value of a country's money was too low, the country would buy its own currency, thereby driving up the exchange value.

The Bretton Woods system successfully lasted until 1971 but the problem arrived when the high rate of inflation and growing trade deficit of USA were undermining the value of the dollar. During the same period, Germany and Japan had favorable balance of payments because they had high volumes of exports. The United States asked the two nations to appreciate their currencies. But the two nations were reluctant to do so as appreciation of their currency would hurt their exports as it will increase the prices of their goods making them internationally incompetent. With the passage of time, the situation in USA went from bad to worse and worst. Finally the Bretton Wood's system was terminated by the then US President Nixon. Now, the USA adopted the 'floating' exchange rate system for USD against other currencies and abandoned the fixed exchange rate system. The exchange value of dollar promptly fell. This alarmed the world leaders who maintained high reserves of Dollar thinking it to be exchangeable for gold. Many countries sought to resuscitate the old Bretton Woods system and proposed the Smithsonian Agreement in 1971 which was similar to Bretton Woods system, but the effort failed. By 1973, various nations, including USA adopted the floating exchange rate system for their currencies. Hence, now the dollar was no more equivalents to gold at a fixed rate but this psychology still persists. This intrinsic co-relation between gold prices and the US dollar still 
exists. When the value of US dollar devaluates in international market bankers as well as investors and traders from all over the world hedge against this adversity through investments in gold. This measure helps them protect the value of their money. The increase in investment demand of yellow metal consequently increases the value of gold. Though the legal connection between gold and USD ended with the Bretton Woods, the current study is an attempt to know if technically any such relationship is still existing in Indian context and what has been the impact of global recession on this relationship.

\section{Literature Review}

The yellow metal has emerged as an important alternative asset only after the equity markets. All over the world the investment demand for gold has surged to new levels when the equity markets were not spared by the global crisis. The performance of the metal has been the area of interest for various academicians and media especially when the gold prices have outperform in recent times. A lot of existing recent literature is available about the relationship between exchange rate of US dollar with respect to the various currencies and gold prices in those nations.

In one of the studies by (Apak, Akman, Çankaya, \& Sönmezer, 2012)the influence of exchange value of various currencies on the prices of gold was analyzed. This study involved currencies of countries that are the leading gold exporters and importers to explain the price fluctuation in gold prices. India, China, Turkey, Russia, USA, Indonesia, Euro zone countries, Switzerland and UK are among the top gold demanding countries whereas, China, Australia, USA, South Africa, Russia, Canada and Indonesia are among the significant producers in World gold production according to various reports of World Gold Council. Further, a subset of alternative assets including bond returns, return on oil prices, silver prices, and credit default swaps of some emerging countries are used. The study employed the GARCH $(1,1)$ model and provided the evidence that return of silver, USD and change in the equity volatility index influences gold returns positively whereas, Swiss Franc and Canadian Dollar returns influence gold returns negatively regardless of the 2008 recession crisis.

In another study, (Omağ, 2012) in analyzed the relationship of yellow metal with few financial variables like inflation, exchange rate of home currency to US Dollar and return on few government securities in Turkey. The most influential factor impacting the gold prices in Turkey is exchange value of home currency to USD. However, the other factors have small but statistically significant impact. He commented that gold is an important precious metal in the economy and the recent recession has increased its investment demand. Therefore, the flow of funds in the financial system has been impacted by effects of gold trading as the metal has emerged as an important alternative investment tool after the recent recession.

In another study, (Kiohos \& Sariannidis, 2010) tried to comment on the influence of energy and financial markets on the gold market in short run. They used crude oil prices an indicator of energy market and equity, currency and exchange rate of U.S. dollar to yen as the indicator of financial markets. In their study, the two used a GJRGARCH model to study these relationships for daily data for 10 year period (January 1, 1999 to August 31, 2009). The study concluded that the exchange rate of U.S. dollar/yen has the most significant impact on the gold prices.

(Sjaastad, 2008) used the technique of forecasting error data to study the relationship between price of gold and exchange rate of major currencies. The study was both empirical and theoretical in nature. It concluded that after the cessation of the Bretton Woods system, the evolution of floating exchange rates for various currencies has been a strong reason behind instability in gold prices. The most influential currency in this respect has been US Dollar. The appreciation or depreciation of US Dollar has been a very important factor in determining the gold prices.

(Tully \& Lucey, 2007) investigated the relationship between gold prices and exchange rate of US Dollar. They used six different models of GARCH family in their study. Their analysis concludes that an APGARCH model is best fit model for the datasets used in the analysis which included data for various economic variables over the 1983-2003 period and both spot and average futures prices of gold. The study provided a especial reference to the equity market crash of 1987 and 2001. The study confirms that the though few macro economic variables have a statistically significant impact on gold prices, the exchange rate of domestic currency to US dollar is the main and important factor which has a strong impact on gold prices.

In another study, (Capie, Mills, \& Wood, 2004) used weekly data for last thirty years for spot prices of gold, exchange rate of Great Britain Pound and Japanese Yen to US Dollar to understand up to what extent gold has acted as a hedge against exchange rate adversities. The study used GARCH model for the analysis. They concluded that the 
relationship between gold and exchange rates of the currencies to USD is inelastic and negative. But the nature and the strength of this relationship has shifted over time. The hedging property of yellow metal is highly dependent on political events and political uncertainty.

(Capie, Mills, \& Wood, 2005) in their study on Gold as a Hedge against the US Dollar did a detailed analysis about if gold is a perfect hedge against US dollar. They collected abundant data for spot prices of gold and the exchange values of currencies from the London markets. They ensured that exchange rate and gold price data were of same day. They checked the relationship of gold with various currencies not only for the entire period but also for various sub periods. The study concluded that gold is a good hedge against adverse exchange value of US Dollar to home currency. The study provided for various statistical evidences for their claims.

In another study (Sinton, 2014), examined the long term association and causality between gold prices, stock indices and U.S Dollar exchange rate in Jakarta. The study used the Johansen Co-integration Analysis for the study and it concluded that there exists no long term association between the variables under study. In another study in Indian context, (Bhunia, 2013) investigated the long term association between crude oil prices, gold prices, US Dollar exchange rate and stock price indices in India. The study also used johansen cointegration and granger causality test and indicated that there exists a long term association between the variables under study. The study further stated that there is a bi directional relationship among the variable under study. However, the study has not segregated the duration of the global financial crisis and included the data since January 1991 to October 2012 at a streach. On similar lines, (Arezki, Dumitrescu, Freytag, \& Quintyn, 2012) used the Johansen Cointegration and granger causality test to find the flow of causality of movement in gold prices and foreign exchange rate in case of prior and post capital account liberalization in South Africa. The findings of the study indicated that the direction of causality was from exchange value of Rand to gold prices in pre libralization phase. However, the flow of causality has revered in post libralization phase.

\section{Objective of the Study}

Keeping in mind the review of existing literature, the objective of the current study will be to understand the long term association and the lead lag relationship between the gold prices and exchange rate of US dollar in Indian economy in three phases: pre global financial crisis, during global financial crisis and post the financial crisis. If the study is able to statistically prove the long term relationship between the variables under study during any of the three phases, then the study will extend its scope to find the lead lag relationship between the two variables under study.

\section{Data Collected}

The data uses spot prices of gold which are collected from the official website of Multi Commodity Exchange Limited (MCX) which is a leading commodity exchange for metal trade in India. The second variable used is the INR- US Dollar exchange rate. The exchange rate data is collected from the official website of International Monetary Fund (IMF). The period of study is divided in three phases:

\begin{tabular}{|ll|ll|}
\hline $\begin{array}{l}\text { Pre Financial Crisis } \\
\text { Period }\end{array}$ & $\begin{array}{l}1 \text { January, 2005 - 30 } \\
\text { November, 2007 }\end{array}$ \\
\hline $\begin{array}{l}\text { During Financial Crisis } \\
\text { Period }\end{array}$ & $\begin{array}{l}1 \text { December, 2007 } \\
2009\end{array}$ \\
\hline $\begin{array}{l}\text { Post Financial } \\
\text { Period }\end{array}$ & Crisis & $\begin{array}{l}1 \text { July, 2009 } \\
2013\end{array}$ \\
\hline
\end{tabular}

The period of the study has been defined after the study of course of event for global financial crisis. (The Economist, 2013) (Shah, 2013) (Elliot, 2011)

\section{Methodology}

The study will use the concept of co integration to check the long term association between the variables under study. The theory of co-integration analysis states that there may be co-integration relationship between the variables involved if they are integrated of the same order. More generally $x_{t}$ and $y_{t}$ are said to be co-integrated of order $C I$ $(d, p)$ if $x_{t}$ and $y_{t}$ are both integrated of order $\mathrm{d}$; but there exist a $\alpha$ such that $y_{t}-\alpha x_{t}$ is integrated of order $d-p$. In other words, the non stationary time series are co integrated if there is a linear combination of $y_{j}$ that is stationary.

The proposed study uses the Johansen co integration test (Johansen, 1988) based on Vector Auto Regression (VAR) to study the long term association between the two variables. The Johansen Co-integration Test is based on a VAR approach to co-integration where it is possible to include the endogenous and exogenous variables. The test relies on the relationship between rank of a matrix and its eigen values or characteristic roots. 
Let,

$$
\Delta x_{t}=\pi x_{t-1}+\mu_{t}
$$

Where,

$\pi=\left(A_{1}-I\right)$

$x_{t}$ and $\mu_{t}=\mathrm{g} \mathrm{X} 1$ vectors

$A_{1}=$ is a $\mathrm{g} \mathrm{X} \mathrm{g}$ matrix of parameters

$\mathrm{I}=$ is a $\mathrm{g} \mathrm{X}$ g Identity matrix

The rank of $\pi$ equals the number of co-integrating vectors. If $\pi$ consists of all zeros, the rank of the matrix equals zero, all of the xs are unit root processes, implying the variables are not co-integrated (Johansen, 1988).

The precondition of co-integration test is that time series need to be integrated of same order. This means that the series need to be stationary at the same lag value. So, to find the stationary of series and we first carried out the unit root test on time series of logarithmic price of exchange rates. A stationary time series will have constant statistical properties. In other words, the statistical properties such as mean, variance, autocorrelation, etc. of a time are all constant over time for a stationary series. Such a series is relatively easy to predict and analyze. To achieve staionarity, if a stochastic process needs to be differenced $\mathrm{i}$ times, the process is said to be integrated of order $i$, and is abbreviated as (i). The statistical properties will be useful for future study only if series is stationary. For example, for a non stationary increasing or decreasing series, the sample mean or any statistical measure will be either underestimated or overestimated. This will mean the models proposed on the statistical measure will be inefficient. Hence, it is required to make the data stationary before we proceed with the test. The most commonly used methods of unit root test is Augmented Dickey Fuller test. The ADF test relies on a parametric transformation of the model that eliminates the serial correlation in the error term. This test is conducted by "augmenting" the preceding three equations by adding the lagged values of the dependent variable $\Delta Y_{t}$.

The Augmented Dickey Fuller Test (ADF Test) was proposed by (Dickey \& Fuller, 1979). The test indicated that under the null hypothesis of unit root (non stationary of data), the calculated statistics $\left(t_{\alpha}\right)$ does not follow the student's t distribution. The statistics is calculated from the following equation:

$$
t_{\alpha}=\frac{\alpha^{\wedge}}{\left(\operatorname{se}\left(\alpha^{\wedge}\right)\right)}
$$

And,

$$
\Delta y_{t}=\alpha^{\wedge} y_{t-1}+x_{t}^{\prime} \delta+\varepsilon_{t}
$$

Where,

$\alpha^{\wedge}$ is the estimate of $\alpha$, and $\left(\operatorname{se}\left(\alpha^{\wedge}\right)\right)$ is the coefficient standard error.

We further use $t$ - statistics to know if our results are significant or not at various levels. The model uses various lag levels till the error component is uncorrelated.

The lead lag relationship between the spot and future market will be treated with the help of granger causality test (Granger, 1969). It is to be noted that although regression analysis deals with the dependence of one variable on the other but it does not provide any evidence that if there is any causal relationship between the variables under study. In other words, we fail to know if any variable is causing the other variable or both of the variables under study are causing each other. Hence, the granger causality test is a step ahead after the regression analysis where one can judge the cause and effect relationship between two variables under study.

The test would use the following pair of regression equations:

$$
\begin{aligned}
& S=\sum_{i=1}^{n} \alpha_{i} F_{t-i}+\sum_{j=1}^{n} \beta_{j} S_{t-j}+\mu_{1 t} \\
& F=\sum_{i=1}^{n} \gamma_{i} F_{t-i}+\sum_{j=1}^{n} \rho_{j} S_{t-j}+\mu_{1 t}
\end{aligned}
$$

Where,

$S=$ Spot Index

$F=$ Futures Index

The significance of results is tested with the help of F- test. F-test is any statistical test in which the test statistic has an F-distribution under the null hypothesis. It is most often used when comparing statistical models that have been fitted to a data set, in order to identify the model that best fits the population from which the data were sampled. 


\section{Findings}

The analysis begins with the graphical representation of the data in the pre, during and post recessionary phase as depicted in figure 1,2 and 3. The graphs indicate that the relationship between two variables under study has been dynamic and inconsistent in nature.

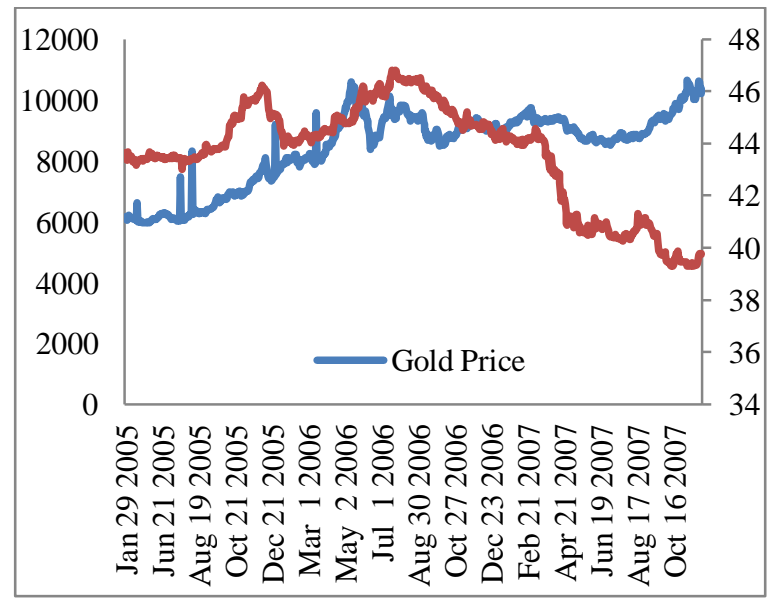

Fig. 1 The Exchange Rate of US Dollar to INR and Gold Prices Jan, 2005 - Nov, 2007

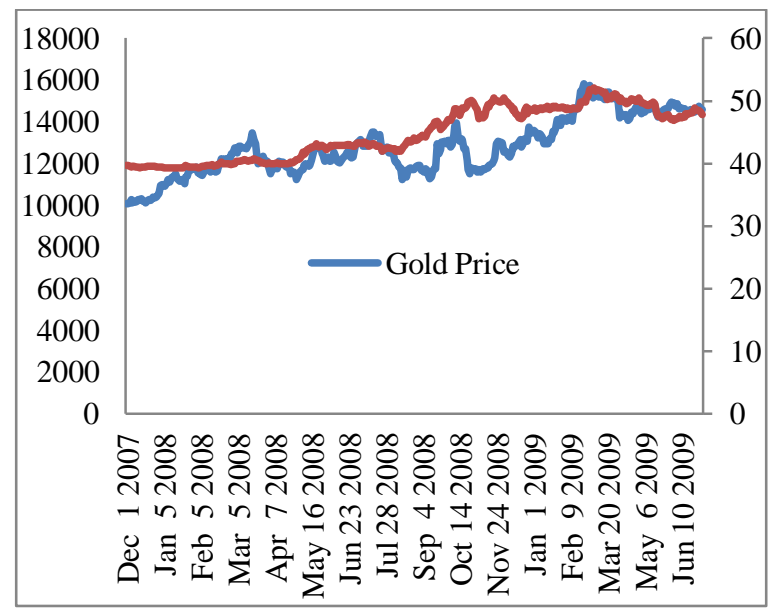

Fig. 2 The Exchange Rate of US Dollar to INR and Gold Prices Dec, 2007 - June, 2009

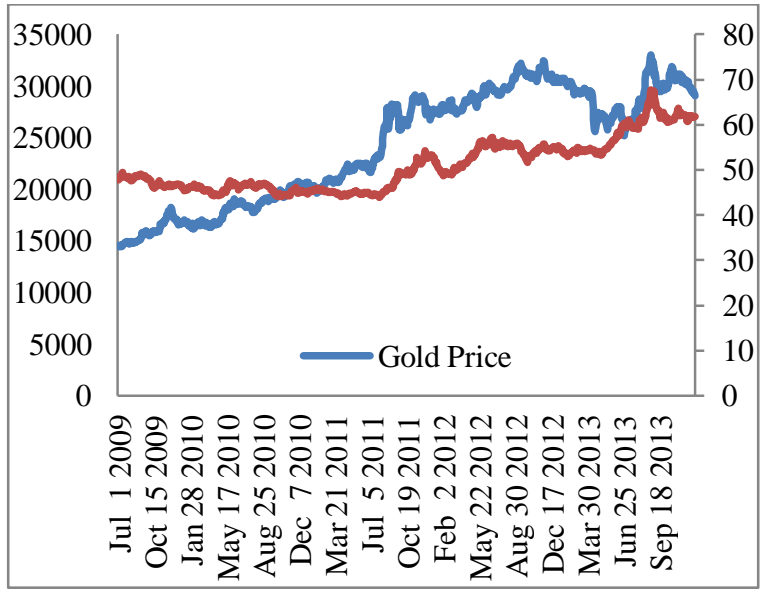

Fig. 2 The Exchange Rate of US Dollar to INR and Gold Prices July, 2009 - Dec, 2013

Proceeding with the study, the series were made stationary using the Augmented Dickey-Fuller test. The Augmented Dickey-Fuller test (ADF) is a test for a unit root in a time series sample. It is an augmented version of the DickeyFuller test for a larger and more complicated set of time series models. The null hypothesis under the test was that the series under consideration has a unit root and is not stationary. The ADF test was first conducted on the data set at level and the following results were derived:

Table 1: The Results of ADF Test on Gold Prices (At Level)

\begin{tabular}{|c|c|c|c|c|c|c|c|}
\hline & \multicolumn{2}{|c|}{$\begin{array}{l}\text { At Level } \\
\text { Jan, } 05 \text { - } \\
\text { Nov, } 07\end{array}$} & \multicolumn{2}{|c|}{$\begin{array}{l}\text { At Level } \\
\text { Dec, } 07 \text { - } \\
\text { June, } 09\end{array}$} & \multicolumn{2}{|c|}{$\begin{array}{c}\text { At Level } \\
\text { July, } 09 \text { - Dec, } \\
13\end{array}$} \\
\hline & & $\begin{array}{l}\text { t- } \\
\text { Stati } \\
\text { stic }\end{array}$ & $\begin{array}{c}\text { Prob } \\
. *\end{array}$ & $\begin{array}{l}\text { t- } \\
\text { Stati } \\
\text { stic }\end{array}$ & $\begin{array}{c}\text { Prob } \\
. *\end{array}$ & $\begin{array}{l}\text { t- } \\
\text { Stati } \\
\text { stic }\end{array}$ & Prob.* \\
\hline \multicolumn{2}{|c|}{$\begin{array}{l}\text { Augmented } \\
\text { Dickey-Fuller } \\
\text { test statistic }\end{array}$} & $\begin{array}{l}0.24 \\
8395\end{array}$ & $\begin{array}{l}0.97 \\
54 \\
\end{array}$ & $\begin{array}{l}- \\
1.07 \\
085 \\
\end{array}$ & $\begin{array}{l}0.72 \\
83 \\
\end{array}$ & $\begin{array}{l}- \\
1.53 \\
83 \\
\end{array}$ & 0.5139 \\
\hline \multirow[t]{3}{*}{$\begin{array}{l}\text { Test } \\
\text { critical } \\
\text { values: }\end{array}$} & $\begin{array}{l}- \\
3.43 \\
858 \\
\end{array}$ & $\begin{array}{l}- \\
3.44 \\
69 \\
\end{array}$ & & $\begin{array}{l}- \\
3.43 \\
59 \\
\end{array}$ & & $\begin{array}{l}- \\
3.43 \\
59 \\
\end{array}$ & \\
\hline & $\begin{array}{l}- \\
2.86 \\
506\end{array}$ & $\begin{array}{l}- \\
2.86 \\
87\end{array}$ & & $\begin{array}{l}- \\
2.86 \\
39\end{array}$ & & $\begin{array}{l}- \\
2.86 \\
39\end{array}$ & \\
\hline & $\begin{array}{l}- \\
2.56 \\
87 \\
\end{array}$ & $\begin{array}{l}- \\
2.57 \\
06\end{array}$ & & $\begin{array}{l}- \\
2.56 \\
80\end{array}$ & & $\begin{array}{l}- \\
2.56 \\
80\end{array}$ & \\
\hline
\end{tabular}


Table 2: The Results of ADF Test on Gold Prices (At First Difference)

\begin{tabular}{|c|c|c|c|c|c|c|c|}
\hline & \multicolumn{2}{|c|}{$\begin{array}{c}\text { At First } \\
\text { Difference } \\
\text { Jan, 05 - }\end{array}$} & \multicolumn{2}{|c|}{$\begin{array}{c}\text { At First } \\
\text { Difference } \\
\text { Dec, 07 - } \\
\end{array}$} & \multicolumn{2}{|c|}{$\begin{array}{c}\text { At First } \\
\text { Difference } \\
\text { July, 09 - Dec, }\end{array}$} \\
\hline & & $\begin{array}{c}\text { t- } \\
\text { Stati } \\
\text { stic }\end{array}$ & $\begin{array}{c}\text { Prob } \\
. *\end{array}$ & $\begin{array}{c}\text { t- } \\
\text { Stati } \\
\text { stic }\end{array}$ & $\begin{array}{c}\text { Prob } \\
*^{*}\end{array}$ & $\begin{array}{c}\text { t- } \\
\text { Stati } \\
\text { stic }\end{array}$ & Prob.* \\
\hline \multicolumn{2}{|c|}{$\begin{array}{l}\text { Augmented } \\
\text { Dickey-Fuller } \\
\text { test statistic }\end{array}$} & $\begin{array}{r}- \\
28.5 \\
17\end{array}$ & 0 & $\begin{array}{r}- \\
19.1 \\
094 \\
\end{array}$ & 0 & $\begin{array}{r}- \\
33.6 \\
66 \\
\end{array}$ & 0 \\
\hline $\begin{array}{l}\text { Test } \\
\text { critical } \\
\text { values: }\end{array}$ & $\begin{array}{r}- \\
3.43 \\
861 \\
\end{array}$ & & $\begin{array}{r}- \\
3.44 \\
69 \\
\end{array}$ & & $\begin{array}{r}- \\
3.43 \\
59 \\
\end{array}$ & & \\
\hline & $\begin{array}{r}- \\
2.86 \\
507 \\
\end{array}$ & & $\begin{array}{r}- \\
2.86 \\
87 \\
\end{array}$ & & $\begin{array}{r}- \\
2.86 \\
39 \\
\end{array}$ & & \\
\hline & $\begin{array}{r}- \\
2.56 \\
871 \\
\end{array}$ & & $\begin{array}{r}- \\
2.57 \\
06 \\
\end{array}$ & & $\begin{array}{r}- \\
2.56 \\
80 \\
\end{array}$ & & \\
\hline
\end{tabular}

Table 1: The Results of ADF Test on USD Exchange Rate (At Level)

\begin{tabular}{|c|c|c|c|c|c|c|c|}
\hline & \multicolumn{2}{|c|}{$\begin{array}{c}\text { At Level } \\
\text { Jan, } 05 \text { - } \\
\text { Nov, } 07 \\
\end{array}$} & \multicolumn{2}{|c|}{$\begin{array}{c}\text { At Level } \\
\text { Dec, 07 - } \\
\text { June,09 }\end{array}$} & \multicolumn{2}{|c|}{$\begin{array}{c}\text { At Level } \\
\text { July, } 09 \text { - Dec, } \\
13\end{array}$} \\
\hline & & $\begin{array}{l}\text { t- } \\
\text { Stati } \\
\text { stic }\end{array}$ & $\begin{array}{c}\text { Prob } \\
*\end{array}$ & $\begin{array}{c}\text { t- } \\
\text { Stati } \\
\text { stic }\end{array}$ & $\begin{array}{c}\text { Prob } \\
\text { * }^{*}\end{array}$ & $\begin{array}{c}\text { t- } \\
\text { Stati } \\
\text { stic }\end{array}$ & Prob.* \\
\hline \multicolumn{2}{|c|}{$\begin{array}{l}\text { Augmented } \\
\text { Dickey-Fuller } \\
\text { test statistic }\end{array}$} & $\begin{array}{l}0.24 \\
8395\end{array}$ & $\begin{array}{l}0.97 \\
54\end{array}$ & $\begin{array}{l}- \\
1.07 \\
085\end{array}$ & $\begin{array}{l}0.72 \\
83 \\
\end{array}$ & $\begin{array}{l}- \\
0.14 \\
11 \\
\end{array}$ & 0.943 \\
\hline \multirow[t]{3}{*}{$\begin{array}{l}\text { Test } \\
\text { criti } \\
\text { cal } \\
\text { valu } \\
\text { es: }\end{array}$} & $\begin{array}{l}- \\
3.4385 \\
8\end{array}$ & & $\begin{array}{l}- \\
3.44 \\
69 \\
\end{array}$ & & $\begin{array}{l}- \\
3.43 \\
59 \\
\end{array}$ & & \\
\hline & $\begin{array}{l}- \\
2.8650 \\
6\end{array}$ & & $\begin{array}{l}- \\
2.86 \\
87 \\
\end{array}$ & & $\begin{array}{l}- \\
2.86 \\
39 \\
\end{array}$ & & \\
\hline & -2.5687 & & $\begin{array}{l}- \\
2.57 \\
06\end{array}$ & & $\begin{array}{l}- \\
2.56 \\
80\end{array}$ & & \\
\hline
\end{tabular}

Table 2: The Results of ADF Test on USD Exchange Rate (At First Difference)

\begin{tabular}{|c|c|c|c|c|c|c|c|}
\hline & \multicolumn{2}{|c|}{$\begin{array}{c}\text { At First } \\
\text { Difference } \\
\text { Jan, } 05 \text { - }\end{array}$} & \multicolumn{2}{|c|}{$\begin{array}{c}\text { At First } \\
\text { Difference } \\
\text { Dec, } 07 \text { - }\end{array}$} & \multicolumn{2}{|c|}{$\begin{array}{c}\text { At First } \\
\text { Difference } \\
\text { July, } 09 \text { - Dec, }\end{array}$} \\
\hline & & $\begin{array}{c}\text { t- } \\
\text { Stati } \\
\text { stic }\end{array}$ & $\begin{array}{c}\text { Prob } \\
*\end{array}$ & $\begin{array}{c}\text { t- } \\
\text { Stati } \\
\text { stic }\end{array}$ & $\begin{array}{c}\text { Prob } \\
. *\end{array}$ & $\begin{array}{c}\text { t- } \\
\text { Stati } \\
\text { stic }\end{array}$ & Prob.* \\
\hline \multicolumn{2}{|c|}{$\begin{array}{l}\text { Augmented } \\
\text { Dickey-Fuller } \\
\text { test statistic }\end{array}$} & $\begin{array}{r}- \\
29.2 \\
206\end{array}$ & 0 & $\begin{array}{r}- \\
19.3 \\
025\end{array}$ & 0 & $\begin{array}{r}- \\
30.0 \\
78\end{array}$ & 0 \\
\hline \multirow[t]{3}{*}{$\begin{array}{l}\text { Test } \\
\text { criti } \\
\text { cal } \\
\text { valu } \\
\text { es: }\end{array}$} & $\begin{array}{r}- \\
3.4385 \\
9\end{array}$ & & $\begin{array}{r}- \\
3.44 \\
69 \\
\end{array}$ & & $\begin{array}{r}- \\
3.43 \\
59 \\
\end{array}$ & & \\
\hline & $\begin{array}{r}- \\
2.8650 \\
7\end{array}$ & & $\begin{array}{r}- \\
2.86 \\
87\end{array}$ & & $\begin{array}{r}- \\
2.86 \\
39\end{array}$ & & \\
\hline & -2.5687 & & $\begin{array}{r}- \\
2.57 \\
06\end{array}$ & & $\begin{array}{r}- \\
2.56 \\
80\end{array}$ & & \\
\hline
\end{tabular}

Since the calculated $t$ - statistics is less than the critical value at various test critical levels for both the series, we have to accept the null hypothesis that the future and the spot prices have a unit root and the series are not stationary. Correspondingly, the ADF test was conducted at the first level difference and the results derived indicated that since the absolute t- statistics is more than the critical value, we reject the null hypothesis meaning that the data is stationary at first difference. Therefore, since the data is integrated of the same order and we can apply the Johansen cointegration test. 
Table 3: The Results of Johansen Co-Integration Test Between Gold USD Exchange Rate

\begin{tabular}{|c|c|c|c|c|}
\hline \multicolumn{5}{|c|}{ Pre Recession } \\
\hline \multicolumn{5}{|c|}{ Unrestricted Co-integration Rank Test (Trace) } \\
\hline \multicolumn{2}{|c|}{ Hypothesized } & Trace & 0.05 & \\
\hline $\begin{array}{l}\text { No. of } \\
\text { CE(s) }\end{array}$ & $\begin{array}{l}\text { Eigen } \\
\text { value }\end{array}$ & Statistic & $\begin{array}{l}\text { Critical } \\
\text { Value }\end{array}$ & Prob.** \\
\hline None & 0.004582 & 32.9323 & 15.49471 & 0 \\
\hline At most 1 & 0.000521 & 0.400548 & 3.841466 & 0.5268 \\
\hline \multicolumn{5}{|c|}{ Unrestricted Co-integration Rank Test (Maximum Eigen value) } \\
\hline \multicolumn{2}{|c|}{ Hypothesized } & $\begin{array}{l}\text { Max- } \\
\text { Eigen }\end{array}$ & 0.05 & \\
\hline $\begin{array}{l}\text { No. of } \\
\text { CE(s) } \\
\end{array}$ & $\begin{array}{l}\text { Eigen } \\
\text { value }\end{array}$ & Statistic & $\begin{array}{l}\text { Critical } \\
\text { Value } \\
\end{array}$ & Prob.** \\
\hline None & 0.004582 & 3.531749 & 14.2646 & 0.0012 \\
\hline At most 1 & 0.000521 & 0.400548 & 3.841466 & 0.5268 \\
\hline \multicolumn{5}{|c|}{ During Recession } \\
\hline \multicolumn{5}{|c|}{ Unrestricted Co-integration Rank Test (Trace) } \\
\hline \multicolumn{2}{|c|}{ Hypothesized } & Trace & 0.05 & \\
\hline $\begin{array}{l}\text { No. of } \\
\mathrm{CE}(\mathrm{s}) \\
\end{array}$ & $\begin{array}{l}\text { Eigen } \\
\text { value }\end{array}$ & Statistic & $\begin{array}{l}\text { Critical } \\
\text { Value } \\
\end{array}$ & Prob.** \\
\hline None & 0.017699 & 8.37506 & 15.49471 & 0.0017 \\
\hline At most 1 & 0.003889 & 1.500057 & 3.841466 & 0.2207 \\
\hline \multicolumn{5}{|c|}{ Unrestricted Co-integration Rank Test (Maximum Eigen value) } \\
\hline \multicolumn{2}{|c|}{ Hypothesized } & $\begin{array}{l}\text { Max- } \\
\text { Eigen }\end{array}$ & 0.05 & \\
\hline $\begin{array}{l}\text { No. of } \\
\mathrm{CE}(\mathrm{s})\end{array}$ & $\begin{array}{l}\text { Eigen } \\
\text { value }\end{array}$ & Statistic & $\begin{array}{l}\text { Critical } \\
\text { Value } \\
\end{array}$ & Prob.** \\
\hline None & 0.017699 & 6.875003 & 14.2646 & 0.0201 \\
\hline At most 1 & 0.003889 & 1.500057 & 3.841466 & 0.2207 \\
\hline \multicolumn{5}{|c|}{ Post Recession } \\
\hline \multicolumn{5}{|c|}{ Unrestricted Co-integration Rank Test (Trace) } \\
\hline \multicolumn{2}{|c|}{ Hypothesized } & Trace & 0.05 & \\
\hline $\begin{array}{l}\text { No. of } \\
\text { CE(s) }\end{array}$ & $\begin{array}{l}\text { Eigen } \\
\text { value }\end{array}$ & Statistic & $\begin{array}{l}\text { Critical } \\
\text { Value }\end{array}$ & Prob.** \\
\hline None & 0.005756 & 7.56101 & 15.49471 & 0.0178 \\
\hline At most 1 & 0.001008 & 1.124482 & 3.841466 & 0.289 \\
\hline \multicolumn{5}{|c|}{ Unrestricted Co-integration Rank Test (Maximum Eigen value) } \\
\hline \multicolumn{2}{|c|}{ Hypothesized } & $\begin{array}{l}\text { Max- } \\
\text { Eigen }\end{array}$ & 0.05 & \\
\hline $\begin{array}{l}\text { No. of } \\
\text { CE(s) } \\
\end{array}$ & $\begin{array}{l}\text { Eigen } \\
\text { value }\end{array}$ & Statistic & $\begin{array}{l}\text { Critical } \\
\text { Value } \\
\end{array}$ & Prob.** \\
\hline None & 0.005756 & 6.436527 & 14.2646 & 0.0035 \\
\hline At most 1 & 0.001008 & 1.124482 & 3.841466 & 0.289 \\
\hline
\end{tabular}

In all the three cases, the Johansen Co- Integration test is conducted with two hypotheses. The first one says that there is no co -integration between the variables under study. The next hypothesis stays that there is co-integration in at most one case. The hypothesis is accepted since the corresponding $\mathrm{p}$ value is more than $5 \%$. The Eigen values in this case also give the same result. Therefore, it can be concluded that the two variables under study have long run relationship.

Since the two variables have long run relationship, the granger causality test was conducted to check the lead lag relation between them. Since the data series becomes stationary at first difference, the test uses the first difference of the original series. The test is conducted at lag which showed the minimum Akaike information criterion (AIC). The minimum value of AIC helps us to know that optimum lag is selected while conducting the Granger Causality Test. The selection of inappropriate lag can lead to skewed result which in turn can define in appropriate lead lag relationship among variables under study. The test showed the following results:

\section{Table 4: The Result of Pair wise Granger Causality Tests between Gold USD Exchange Rate}

\begin{tabular}{|c|c|c|c|}
\hline & $\begin{array}{c}\text { F- } \\
\text { Statistic }\end{array}$ & $\begin{array}{c}\text { Prob } \\
.\end{array}$ & $\begin{array}{c}\text { Decisio } \\
\mathbf{n}\end{array}$ \\
\hline \multicolumn{4}{|l|}{ Pre Recession } \\
\hline \multicolumn{4}{|l|}{ Null Hypothesis: } \\
\hline $\begin{array}{l}\text { USD1 does not Granger Cause } \\
\text { GOLD1 }\end{array}$ & 0.4602 & 0.005 & $\begin{array}{c}\text { Rejecte } \\
\mathrm{d}\end{array}$ \\
\hline $\begin{array}{l}\text { GOLD1 does not Granger Cause } \\
\text { USD1 }\end{array}$ & 1.01568 & $\begin{array}{r}0.008 \\
3\end{array}$ & $\begin{array}{c}\text { Rejecte } \\
\mathrm{d}\end{array}$ \\
\hline \multicolumn{4}{|l|}{ During Recession } \\
\hline \multicolumn{4}{|l|}{ Null Hypothesis: } \\
\hline $\begin{array}{l}\text { USD1 does not Granger Cause } \\
\text { GOLD1 }\end{array}$ & 1.20899 & $\begin{array}{r}0.306 \\
5\end{array}$ & $\begin{array}{l}\text { Accept } \\
\text { ed }\end{array}$ \\
\hline $\begin{array}{l}\text { GOLD1 does not Granger Cause } \\
\text { USD1 }\end{array}$ & 1.63732 & $\begin{array}{r}0.164 \\
2\end{array}$ & $\begin{array}{l}\text { Accept } \\
\text { ed }\end{array}$ \\
\hline \multicolumn{4}{|l|}{ Post Recession } \\
\hline \multicolumn{4}{|l|}{ Null Hypothesis: } \\
\hline $\begin{array}{l}\text { USD1 does not Granger Cause } \\
\text { GOLD1 }\end{array}$ & 5.74535 & $\begin{array}{r}0.000 \\
1 \\
\end{array}$ & $\begin{array}{c}\text { Rejecte } \\
\mathrm{d}\end{array}$ \\
\hline $\begin{array}{l}\text { GOLD1 does not Granger Cause } \\
\text { USD1 }\end{array}$ & 2.05963 & 0.084 & $\begin{array}{l}\text { Accept } \\
\text { ed }\end{array}$ \\
\hline
\end{tabular}

The results and decision of granger causality test are given in table 4. The null hypotheses are rejected in case the $p$ values are less than 0.05 . On the other hand, in case the $p$ values are more than 0.05 , the null hypothesis is accepted. As a result, the test indicates that there exists bidirectional 
causality between exchange rate of USD and gold prices in India before the recession. However, this bidirectional relationship is disturbed and there exists no lead lag causality between the variables during the period of global recession. However, post recession; the causality flows from exchange value of USD to gold prices in India.

\section{Conclusion}

The study concludes that the relationship between gold prices and USD exchange rate has been impacted by recession in India. The two variables under study shared bidirectional causality (Bhunia, 2013) before recession which was lost during the global financial turmoil in 2007 2008. The Indian economy faced the problem of USD appreciation post recession due to stressful global macroeconomic scenario (McCauley \& McGuire, 2009) (Quéré, Béreau, \& Mignon, 2009). As a result, the gold prices also sky rocketed. This direction of causality in the prices is well evident from the result of granger causality test summarized in table 4 . The study hence concludes that exchange value of US Dollar is an important factor in fluctuations in gold prices in India like in case of South Africa as concluded by (Arezki, Dumitrescu, Freytag, \& Quintyn, 2012). Even though this relationship has changed with the occurrence of global recession, the exchange value of USD should be taken into consideration while taking any investment decision in the metal (Tully \& Lucey, 2007)

\section{Bibliography}

Apak, S., Akman, V., Çankaya, S., \& Sönmezer, S. (2012). The Case for Gold Revisited: A Safe Heaven or A Hedge ? Emerging Markets Journal , 2, $1-8$.

Arezki, R., Dumitrescu, E., Freytag, A., \& Quintyn, M. (2012). Commodity Prices and Exchange Rate Volatility: Lessons from South Africa's Capital Account
Liberalization. IMF Working Paper,

WP/12/168, 1-19.

Bhunia, A. (2013). Cointegration and Causal Relationship Among Crude Price, Domestic Gold Price and Financial Variables- An Evidence of BSE and NSE. Journal of Contemporary Issues in Business Research, 2 (1), 1-10.

Capie, F., Mills, T. C., \& Wood, G. (2005). Gold as a hedge against the dollar. International Financial Markets, Institutions and Money, 15, 343-352.

Capie, F., Mills, T. C., \& Wood, G. (2004). Gold as a Hedge against the US Dollar. World Gold Council, Research Study No 30 .

Dickey, D. A., \& Fuller, W. A. (1979). Distribution of the Estimators for Autoregressive Time Series with a Unit Root. Journal of the American Statistical Association, 74, 427-431.

Elliot, L. (2011, August 11). Global financial crisis: five key stages 2007-2011. Retrieved October 31, 2013, from http://www.theguardian.com: http://www.theguardian.com/business/2 011/aug/07/global-financial-crisis-keystages 
Granger, C. (1969). Investigating causal relations by econometric models and cross-spectral methods. Econometrica, 37, 424-438.

Johansen, S. (1988). Statistical analysis of cointegration vectors. Journal of Economic Dynamics and Control , 12, 231-254.

Kiohos, A., \& Sariannidis, N. (2010). Determinants of the asymmetric gold market. Investment Management and Financial Innovations , 7 (4), 26-33.

McCauley, R. N., \& McGuire, P. (2009). Dollar appreciation in 2008: safe haven, carry trades, dollar shortage and overhedging. BIS Quarterly Review, 85-93.

PWC. (2013). The direct economic impact of gold. World Gold Council.

Quéré, A. B., Béreau, S., \& Mignon, V. (2009). The Dollar in the Turmoil. Journal of the Japanese and International Economies , 23 (4), 427-436.

Shah, A. (2013, March 24). Global Financial Crisis. Retrieved October 20, 2013, from http://www.globalissues.org: http://www.globalissues.org/article/768 /global-financial-crisis
Sinton, J. (2014). An Empirical Investigation of the Causal Relationship between Gold Price, Exchange Rate Changes and Jakarta Composite Index. Proceedings of World Business and Social Science Research Conference, (pp. 1-10). Paris.

Sjaastad, L. A. (2008). The Price of Gold and the Exchange Rates: Once Again. Resources Policy, 33 (2), 118-124.

The Economist. (2013, September 7). The origins of the financial crisis: Crash course. Retrieved October 1, 2013, from http://www.economist.com: http://www.economist.com/news/schoo 1sbrief/21584534-effects-financialcrisis-are-still-being-felt-five-yearsarticle

Tully, E., \& Lucey, B. M. (2007). A Power GARCH Examination of the Gold Market. International Business and Finance, 21, 316- 325. 